EthnoAnthropoZoom

$550.34(497.711) » 1963 »(093.3)$

\author{
Blaž Andoljšek, (Slovenia) \\ Department of Ethnology and Cultural Anthropology \\ The University of Ljubljana \\ E-mail: bandoljsek@gmail.com
}

\title{
THE GROUND WAS TREMBLING WHOLE NIGHT: MEMORIES AND STORIES OF THE SKOPJANS ABOUT THE DEVASTATING EARTHQUAKE IN 1963.
}

\begin{abstract}
On the 26th of July tremendous earthquake occurred, which destroyed around 80 percent of the city. More than 1,070 people died. However, memories of people who survived it are still very lively. Besides all damage that was left behind, it also lit up solidarity from all around the globe. Donations and help came from many countries. The article will focus on life stories and memories of how they remember happening before, during, and after the earthquake. Today we can still find reminders that show us that difficult period, such as a broken clock at the Old Railway Station.
\end{abstract}

Keywords: Anthropology of Catastrophe, Life Stories, Earthquake

\section{Introduction}

My article is based on the literature and interviews I did on a student Erasmus exchange at the University of Cyrill and Methodius, Institute of Anthropology and Ethnology in Skopje. My first exchange was five months in 2018, and another one was one year later, in 2019. I planned to return in 2020 for few months, but at the same time, covid-19 pandemia started, so I could not finish all goals I had for the fieldwork. However, in those months of living in Skopje, I managed to speak with many people who survived the tremendous earthquake in 1963.

My first encounter with the topic was on a spring day in 2018 while having a coffee at my friend's house. I met his grandmother, with whom I spoke about her life and the history of Macedonia, and she also mentioned the earthquake. It got my attention immediately, and that is how I started the research. Other interviewers, I mainly found on the Facebook group ,Stari Skopjani` and also with a big help from Skopje Urban Living Lab SkULL, for what I would like to thank Mrs. Lidija Kekenovska Pavikj and to the whole Institute for Ethnology and Anthropology where I always found help and guidance for my master thesis. 
EthnoAnthropoZoom

\section{Macedonia As An "Earthquake Area":}

Earthquakes are one of the most "terrifying and fascinating natural phenomena occurring on the Earth /.../. They are powerful enough to destroy civilizations and turn cities into ghost towns". (Timovska 2011: 2). It is "the result of a sudden release of energy in the Earth's crust that creates seismic waves. (ibid.:3). Macedonia is located "in the Mediterranean seismic belt /.../ and it is quoted by many authors (e.g. Montessus de Ballore, Sieberg, Gutenber, Richter, etc.) as an area of high seismicity“ (Petrovski 2004: 1). Even in the past Vardar zone was considered as a "region where earthquakes occur pretty frequently. (ibid.: 2) Nevertheless, "there is only incomplete documentation on this phenomena until 1905 when the Seismological Institute of Belgrade was founded. (ibid. 1-2). In 1950 was published "first seismological map of Yugoslavia" which includes "intensities of the observed earthquakes in the period from 360 A. D. to 1950«. (Petrovski 2004: 2) The map was "used as a seismic zoning map of Yugoslavia with the Temporary Code for Aseismic Design of Buildings enforced in 1964 /.../, after the lessons learned from Skopje Earthquake in 1963. (ibid.: 2)

1963 was not the first destroying earthquake in Skopje. The area of Skupi in 518 was destroyed due to the earthquake. After that, the city was rebuild, but another catastrophe occurred in 1555. The town was demolished once again. (Janevski 1970: 247)

The third one happened on the 26th of July in 1963 at 5.17, when most inhabitants were still sleeping. It lasted few 10 seconds with many aftershocks. Earthquake "destroyed 16,000 homes and damaged some 30,000 more, leaving 1,070 people dead, 3,300 people injured and around 200,000 people homeless" (Kritikos 2019: 12).). It was destroyed around 80 percent of the city. (Sinadinovski and McCue: 2013: 1). In that period Skopje had 8102 appartments. (Jovanovski 2014: 2). It was a shallow earthquake with magnitude $M=6.1$ by the Richter scale "with an intensity rating of IX (Mercalli scale). /.../ The material losses were estimated about one billion US dollars" (Sinadinovski and McCue 2013: 3) Majority of the territory of the Republic in Macedonia, which is 25,700km2 "was shaken with intensities between V and IX on the Mercalli scale. (ibid: 3)

People with whom I talked mainly spoke about how an earthquake marked their life, so we can say that they were telling me their life stories. Life story "is a simple, a person's account of their life, or of what they think is a significant part of their life. It is, therefore, a personal narrative, a story of a personal experience, and, as it emerges from the conversation, its ontological status is the spoken word "(Titon 1980: 276). An earthquake is a disaster, which is "an event, and a disaster is a language. In their outward contours, some disasters are brief and acute. In contrast, others are long-lived and chronic" (Stein 2002: 157). Anthropologist Stein believes that when we listen to stories about the disaster, it means "to listen to the people whom we are trying to help, better than we listen to our theories and methods. «(ibid. 159). We have to ask ourselves what it is like to be in their shoes. (ibid.: 159). Regina Bendix claims that "personal narratives are /.../ the primary means at an individual's disposal to regain order out of chaos. (1990: 333). Earthquake stories do "illustrate with astounding clarity the interplay between an event, the personal experience thereof, and the structuring of this experience in a meaningful fashion" (ibid 333). My interviewers spoke more or less in the same sequence; memories before, during, and after the earthquake. I had prepared semi-structural interviews, so they main- 
ly spoke by themself fluently. I would like to present some parts of their stories from those three sequences.

\section{Before The Earthquake}

Mister Branislav remembers the night before the earthquake:

"It was a warm night. I was spending time with my friends. We went to my friend's place, and we're drinking, and we listened to music on a gramophone. I slept at his place. His family already slept. It was around 2 in the morning when I fall asleep. I woke up in a hospital. When the earthquake occurred, I felt like something is trembling. I took a blanket and covered myself over my head. I felt like I cannot move due to some board that fell on my leg. The blanked saved me that I did not suffocate with dust /.../ In that accident, my friend died, his mother and his sister as well. After some time, I went to Zenica for rehabilitation. Two months after there was another earthquake in Sarajevo. I sat on the balcony while it started trembling. I was afraid". work.

Mister Sotir was awake since early in the morning as he was getting ready for

"It was summer, the 26th of July. I was getting ready to go to work. I was in the kitchen, making breakfast, and suddenly everything started to tremble, and that was very intense /.... . After that, it was many aftershocks. Everything that was on the stove fell. My father, who was getting ready to go to work, was in the living room. When he was tieing his shoes, it happened earthquake. He went by instinct down the stairs, and I told him "come back". I could not go to the living room. There was a radio and sofa, and the radio fell between the door and the couch, so I could not open the door. My grandpa had more than 90 years. My father carried him and took him out. My mother, sister, and brother were in the bedroom. I somehow was not afraid. They all went out in pajamas, except I was fully dressed, as I was getting ready for work".

Mrs. Snežana, who sadly deceased this year, was a child, and she was telling me that a night before the earthquake they:

"heard animals from the ZOO screaming. They were upset all night long. I think many people survived, according to them, as they could not sleep and were awake. I still remember those noises. /.../ We lived in the city center in a building. Our apartment was on the 9th floor. The door was blocked due to a fallen closet. It was good that they were blocked; otherwise, we might die on the stairs. The architect of our building was a man who did a project also for Sindicat's building. He was accused that he spent too much material on building. Ironically, those buildings in my area that he made were the only ones which were not collapsed in the earthquake". 
Another person lived next to the old Railway station. He was telling me that in that period, he had a lot of guests at his home. They were from:

"Serbia and Bulgaria, and I remember that it was a whole house of people. I slept with my grandmother on the ground floor. I remember the first time when it happened. It was trembling a lot /.../ I know that it lifted me from the bed. When aftershock came, we were at the door, but we were not able to open it. I heard neighbors who passed by our courtyard, and they said that the atomic bomb attacked the city and that war began. We did not know that it is an earthquake. /.../ When we came to the street, it was already the third aftershock. Suddenly - as I lived in front of the train station there was a vast cloud through the road. It was a cloud made of dust. /.../ The most I remembered one guy who climbed on the roof of Mercedes and he said,» People, let's organize ourselves and let's start to dig into the ruins and start looking for people" That was maybe 15 minutes after the earthquake."

Mrs. Jelica, who sadly deceased two years ago, remembers that they moved to the house in Hipodrom just a short period before the earthquake.

"I woke up very early in the morning. Kids - Sneska was still tiny; she had two years. Zore had four years, and Lence is the oldest one. We slept in the bedroom when the daughters woke up. I told my husband that it is still early and that I will try to sleep a bit more. He should have wake up and get ready for work/.../daughters went to the kitchen, and then one of them came to me, and she said she wants to eat bread. I told her: "Why would you like to eat bread? It is early, it is 5 in the morning" And then, all of a sudden, it exploded. Everything started to shake".

The following story I got from a person who contacted me after I wrote a post in the Facebook group Stari Skopjani that I am looking for people willing to speak about the earthquake. He sent me a letter from Mr. Dragan. He was a child that period, and he was on the way to the train station, as his family planed vacation in Struga.

"When we left the house, it was 5.10 oclock. I was excited. My father carried a suitcase, and in a moment when he stepped on the first stairs, the bag broke, and it fell apart. I do not know if that was a coincidence or some force that saved us, so we did not go to the train station. When I looked towards the House of Army, it was 5.15 oclock, two minutes until the catastrophe. We walked fast to catch the train, and suddenly we heard a distant bang which was coming more and more towards us".

\section{During The Earthquake}

During the earthquake, my interviewers spoke mostly with emotions and described how difficult it was. That kind of traumatic event "arises when a horrific event occurs and danger mechanisms are engaged, but they can in no way stop or facilitate the possibility. As a result, everything happening in the body that is meant to help a person 
resist, flee from, or intervene in the horror, cannot serve its purpose». (Phillips 2017: 23). Many of them were speaking about horrific sounds during the earthquake.

Mrs. Snezana said:

"Every Skopjes earthquake has a specific terrific sound. It is like roaring from the underground. I still remember this sound very lively".

Mr. Dragan's memories are still very lively about the happening during the earthquake.

"The ground was shaking, my legs began to move, and everything started to fall apart around me. I did not know what was happening. Some woman exclaimed: "Son, lay down; it is an earthquake!" The dust flew all around; I could not see what is going on. Terrified, I heard my father how he calls my name: "Dragance, Dragance, where are you?" I screamed back: "Father, father, "completely blind due to the dust around. The ground was still trembling. I stood up but immediately fell. It was not possible to standing still. All of a sudden began to calm down, and I started to look for my parents. The dust was like a mist, impossible to see anything. Suddenly someone grabbed my hand. It was my father and me who started to cry. At the same moment, I saw my mom. We were running behind the Parlament. There was a little guardhouse, and inside was a policeman. He exclaimed: "Run, this is a war, Yugoslavia is being attacked. "It started to trembling again as we fell to the ground. The building was collapsing; bricks were falling all around, the dust was everywhere. We could not breathe. Then it began to calm down, and we stood up. I still relive that fear today." Mrs. Jelica remembers that everything began to shake.

"The chandelier bounced in all directions. I stood up all of a sudden. My husband could not stand up. I told him: "Get up, run and take the children. I went behind the door, which began to slam on the kids. Behind the door, there was a chimney in the bedroom. It collapsed, but fortunately, towards the hallway. When I took the kids, bricks began to fell. Kids were crying. If they were here, the chimney would fall on them, and it would crush them; they were still little. My husband was wondering what it was: "Are those tanks?"

I said: "get up, it is an earthquake. "He still could not stand up as everything was shaking. Lence, the older daughter, was sleeping. My husband took her, and we went out. We looked towards our neighbors' house, and it was all in smoke. I said: "Oh god, it is on fire, "but it was not the fire, but it was dust from collapsed buildings. Another neighbor was outside, and she ran into her house to call her son. He was a soldier, and he was not at home that day. She fell; everything was shaking. Then I looked to the third neighbor; they were rescuing kids through the window. Next to their door boiler fell, so they were not able to go through the door. Everyone was screaming: "Oh god, what is this? earthquake!" 


\section{After The Earthquake}

Most of the interviewers marked people were in solidarity with each other, but also they felt solidarity from the whole world. They exposed help from all around the world. But, on the other hand, they spoke about the problematic consequences which the catastrophe brought.

Mr. Sotir, who said that he was not afraid during the earthquake, told me that when he went to the city center to help others, he was scared when he saw the reality.

"When I saw old houses wholly collapsed, I realized what just happened. At that moment, I saw the reality of the earthquake /.... The dust on the cars was thick for around 10 centimeters. We organized ourselves quickly. We, young people, organized brigades for help. We cleaned the city, we helped in libraries to save books and in pharmacies to keep medicines. We managed ourselves also in a cultural way. We organized events, so we felt more that we are still in civilization. We arranged singing and dancing contests, so life was more bearable. Everything was based on a friendship. /.../ Help came from all around the world. The hospital was made by Romania, University hall from Bulgaria, schools from Norway. Solidarity was on the top. Mostly it was help, friendship, and solidarity. /.../ But we also had a curfew for one month to prevent if someone would try to steal something from homes. But mostly, it was friendship, help, and solidarity. /.../ The city at that time was small, it was not big like today. We knew almost everyone. All generation was together, but after the earthquake, we were connected even more. It was not everything so dark. We were dancing oro; we had shown ".

Mr. Dragan wrote that he could not forget the scene after the earthquake. »

"People were half-naked. On my left side, there was collapsed house, and an old woman stood there with soil in her hands and crying: "My grandchild was in the place, please help me. "Another older woman approached me, and she gave me lemonade. "Drink, son, so you will not be so afraid anymore. "I drank the lemonade, but I was even more terrified. I looked around myself, and I saw that the old Railway station was destroyed. People started to speak that the Bank, Post office, House of the Army were destroyed as well. I listened to them, and I could not believe that my Skopje disappeared in just a few seconds. I started to cry. I looked at my father, and he seemed calm. He went to check if his brothers and sisters are alright. /... When we came home, our neighbors screamed: "You are alive! We thought that the train station fell on you!" If my suitcase would not break, I would not hugging my mother and father and would not be able to see the stars that night. The ground was still trembling the whole night. "

Mrs. Jelica's family, who lived in the area of Hipodrom, did not know how many buildings very destroyed.

"Slavko took his bicycle, and he wanted to go to the city center to report that our chimney collapsed. We just built our house. /.../ His brother said to him: "Where are you going?" and my husband responded: "I am go- 
ing to the city to report that my chimney collapsed and that the house is all in cracks. "His brother said: "What is wrong with you, where are you going?! The House of Army collapsed, train station, the city is destroyed. Stay at home". /.../ It was terrifying. We went to the meadow where our neighbors gathered. Where will we sleep? We put beds on the terrace under the pear tree. /.../ Around the highway was terrible; people were walking in pajamas, people were bloodied, some of them were naked. Some days after, I was still shaking all the time. All august, we slept outside with my brother. In September, we came back when kids had to go back to school".

Some people described Skopje as it looked in a war zone:

"Skopje looks like it is in a war. It is dark on the streets, ruins, desert - there is no man around. Just police officers are taking care of the dead city. This is Skopje today - European Hiroshima. Hiroshima in peace. And during the day, it is empty. On the balconies are withered flowers. No one would water them. At the entrances of the buildings, you can find pieces of paper. On some paper is written: "Mommy, I am alive. I am in the area of Taftalidze, tent number 12." On the other was written: "Pero, Nikola! We are all in the tents, around the park, next to the monument of Goce Delcev. Do not enter in the house". (Navmovska in Šopov 2014: 53)

Mrs. Snezana remembers how rats appeared everywhere after the earthquake.

"We lived on the 9th floor, and I remember that my mother was later scared of rats. As soon earthquake began, all rats started to run up to higher grounds. Rats were everywhere, a lot of them".

\section{Skopje Today}

After the earthquake, they began to rebuild the city. Usually, after earthquakes, there is a rule that» emergency buildings, infrastructure facilities, and residential structures take the least time. Health, educational and administrative facilities take an intermediate time. Multi-use and cultural buildings take the most time". (Al-Nammari, Lindell 2009: 472) The least cost is for residential structures, emergency buildings, and infrastructure facilities. An intermediate amount of cost is required for administrative, cultural, educational, and health facilities. The greatest cost is for multi-use buildings." (Al-Nammari, Lindell 2009: 472) For rebuilding the city where collaborated many architects from Yugoslavia, but also from all around the globe. Tito's words,» Skopje survived an unseen catastrophe. Still, we shall build the city again with the help of our entire society, thus making it our pride and the symbol of our brotherhood and unity, both for Yugoslavian and international solidarity" officially »started the reconstructed process. «(Tolic 2019: 40). We can still find those words today "on Skopje's former railway station, a building that became the symbol of the devastation and which today serves as the City Museum. (ibid.)

Moreover, there is still a clock on the facade of the Old Railway Station in Skopje, which "stopped at precisely 05.17 on the 26th of July, 1963." (Kritikos 2019: 11) Such fro- 
zen timepieces often mark disasters. (ibid.) Kritikos says that the expression of "even a broken clock is right twice a day, gains a more profound meaning; every twelve hours, one can be reminded that the moment when the particular clock stopped working was as real as any other moment on any given day. «(ibid 11-13). On the other hand, it shows that the» clock has been left broken, juxtaposing its state with the rest of the city that has moved on. «(ibid 12-13). It is also a reminder of the» manifestation of international solidarity, a moment of history that is important not only to the citizens of Skopje but also to the whole world. (ibid.)

At this point, I would like to emphasize words from mostly all of my interviewers: "Da ne se povtori nikogas" (never to not be repeated ever again (earthquake). " 


\section{References}

Јаневски, Славко ур. 1970. Скойје. Београд: Младост.

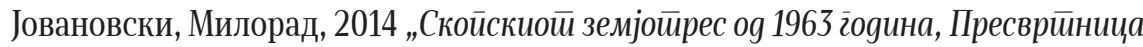

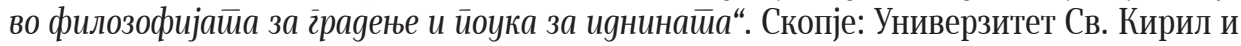
Методиј, Градежен факултет Скопје.

Наумовска, Сенка и Иван Шопов, 2014 „50 гоgини оg земјойресой во Скойје: Скойје - анииичко или модерно. Скопје: Темплум.

Al-Nammari, Fatima, Lindell, Michael K. 2009. „Earthquake recovery of historic buildings: Exploring costs and time needs“. Disasters 33 (3), 457-481. (4), 331-347.

Bendix, Regina 1990. „Reflections on Earthquake Narratives“. Western Folklore 49

Kritikos, Christos-Georgios 2019. „The days after: Skopje's first steps towards reconstruction“. The Future as a Project. Hellenic Institute of Architecture.

Petrovski, T. Jakim 2004. „Damaging Effects of July 26, 1963“. MESF Cyber Journal of Geoscience (2).

Phillips, Elizabeth 2017. „Narrating Catastrophe, Cultivating Hope: Apocalyptic Practices and Theological Virtue“. Studies in Christian Ethics 31 (1), 17-33.

Sinadinovski, C., McCue, K. F. 2013. „50 years since the Skopje 1963 Earthquake: Implications for Australian building standards“. Australian Earthquake Engineering Society 2013 Conference. Hobart Tasmania.

Stein, F. Howard 2002. „Toward an Applied Anthropology of Disaster: Learning from Disasters - Experience, Method and Theory“. Illness Crisis \& Loss 10 (2), 154-163.

Timovska, Maja 2011. „Using knowledge to save lives in case of earthquake“. Technology, informatics and education for learning and knowledge society. 6th International Symposium. Technical Faculty Čačak.

Titon, Jeff Todd 1980. „The Life Story“. The Journal of American Folklore 93 (369), 276-292.

Tolic, Ines 2019. „The Protagonists of Skopje's Reconstruction“. The Future as a Project. Hellenic Institute of Architecture. 